\title{
Health risk assessments due to uranium contamination of drinking water in Bathinda region, Punjab state, India
}

Lakhwant SINGH, Rajesh KUMAR, Sanjeev KUMAR, B.S. BAJWA, Surinder SINGH

(Manuscript received 5 April 2012, accepted 20 September 2012)

ABSTRACT The mass concentration of uranium in water samples collected from the Bathinda district of Punjab state, India, was estimated using the laser fluorimetric technique. The study region has shown a pronounced number of cancer cases in the recent period. The study aims to calculate the human radiological risk and chemical toxicity associated with uranium consumption through drinking water. The mass concentration of uranium was found to vary from 0.48 to $571.7 \mu \mathrm{g} / \mathrm{l}$ with a mean value of $84.70 \mu \mathrm{g} / \mathrm{l}$. The radiological risk due to consumption of uranium through contaminated drinking water was observed to be in the range of $1.34 \times 10^{-6}$ to $1.60 \times 10^{-3}$ with a mean value of $2.37 \times 10^{-4}$. The chemical toxicity was found to vary from $0.04-43.11 \mu \mathrm{g} \cdot \mathrm{kg}^{-1} \cdot \mathrm{day}^{-1}$ with a mean value of $6.38 \mu \mathrm{g} \cdot \mathrm{kg}^{-1} \cdot \mathrm{day}^{-1}$.

Keywords: uranium / radiological risk / chemical toxicity / laser fluorimeter

\section{Introduction}

Uranium, a long-lived natural radionuclide present in rocks, soil, natural materials, water, air and food, plays a vital role in delivering the dose to the public through terrestrial exposure, inhalation and ingestion. Uranium enters the human body mainly through water, air and food. So, accurate knowledge of the concentration of uranium in water helps in estimating the dose due to uranium. Uranium exists in oxidation states of $+4\left(\mathrm{UO}_{2}\right.$ and $\left.\mathrm{U}^{4+}\right)$ and $+6\left(\mathrm{UO}_{3}\right.$ and $\left.\mathrm{UO}_{2}{ }^{2+}\right)$ in its compounds. Uranium bonds with oxygen to form uranyl ion or uranium dioxide, which is soluble in groundwater under aerobic conditions. Uranium dissolves readily in oxygen-rich water, which accounts for its presence in surface water, groundwater and seawater. The hexavalent state of uranium commonly associated with $\mathrm{UO}_{2}{ }^{2+}$ is more significant in water, whereas this state of uranium is insoluble in almost all tetravalent compounds (Sahoo et al., 2009).

Department of Physics, Guru Nanak Dev University, Amritsar 143005, India.

* rajeshmahajan53@gmail.com 
It has been established that concentrations of uranium in drinking water above permissible limits may produce harmful biological effects in humans (WHO, 2008). The health effects of uranium can be divided into carcinogenic and noncarcinogenic effects (Health Canada, 1999; WHO, 1998) and these classifications are based on the radiological risk (carcinogenic) due to radiation of uranium isotopes and the chemical toxicity risk (non-carcinogenic) due to uranium as a heavy metal. The toxic effects of uranium compounds have been extensively studied in the kidney (Kurttio et al., 2002). It was found that uranium is toxic to kidneys. However, in 2006, Kurttio et al. found that even at higher exposures uranium was not cytotoxic (Kurttio et al., 2006). The toxic effects of uranium on the bones of laboratory animals were studied, showing that uranium deposition is part of the metabolic process, and showing the uranium concentration in the bones of populations exposed to significant uranium intake (Larivière et al., 2007). It was found that uranium in the range of 0.004 to $9 \mu \mathrm{g} /(\mathrm{kg}$ body weight $)$ may produce interference with kidney functions (Zamora et al., 1998). A study on a Finnish population exposed to well water containing a median uranium concentration of $28 \mu \mathrm{g} / \mathrm{l}$ examined individuals for signs of adverse renal effects (Kurttio et al., 2002). The development of toxicity due to uranium has been studied in mice (Dominigo et al., 1989) and a reduction in maternal weight gain, reduction in daily feed intake and increase in liver weight have been observed.

In the Bathinda region, the authors have already measured high concentrations of uranium in some water samples (Singh et al., 1994). Therefore, it is necessary to study in detail the measurement of the uranium contents in the water and to determine the health risk to the human body. In the present paper, we measured and report the mass concentration of uranium in water samples collected from the different sources of water bodies in the Bathinda region of Punjab state, India. 159 drinking water samples were collected in this region from different locations, different sources and different depths to evaluate the radiological risk and chemical toxicity due to uranium in drinking water.

\section{Description of study region}

Bathinda district is situated in the south-western region of Punjab State in Northern India. Bathinda district extends between $29^{\circ} 33^{\prime}$ and $30^{\circ} 36^{\prime}$ north and from $74^{\circ} 38^{\prime}$ to $75^{\circ} 46^{\prime}$ east and lies at an average elevation of $300 \mathrm{~m}$ above sea level. The study region is darkened on the map of Punjab state, India, as shown in Figure 1. The study region forms a part of the Indo-Gangetic Alluvial Plains. The temperature and relative humidity in the area lie in the range of $34-49{ }^{\circ} \mathrm{C}$ and $18-48 \%$ (during summer) and $2-10{ }^{\circ} \mathrm{C}$ and $60-73 \%$ (during winter), respectively. The soil of the study region is loose and sandy. The soil consists of different layers of clay, sticky clay and fine- to coarse-grained grey micaceous sandstone. The top layer of soil is 


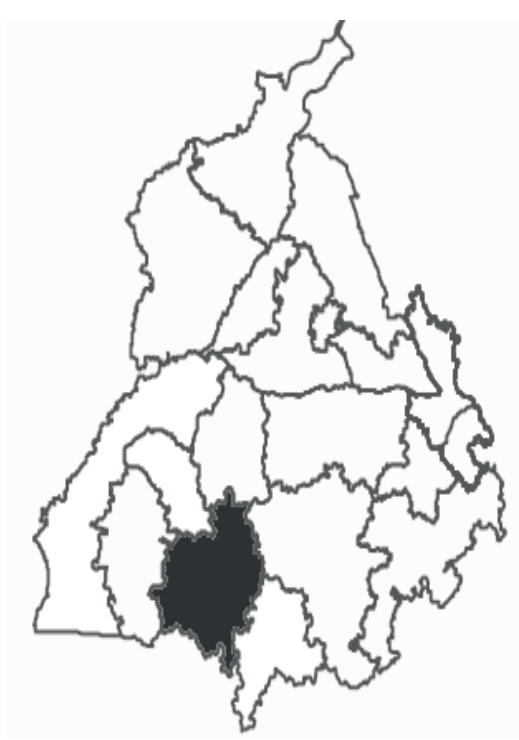

Figure 1 - Dark area shows the study region on the map of Punjab State, India.

dark reddish silty soil rich in $\mathrm{CaCO}_{3}$. The hydrogeology of this region is characterised by unconfined and confined aquifers down to $50 \mathrm{~m}$ depth (Gill et al., 2005). The land is predominantly used for agricultural purposes. However, Bathinda district has two thermal power plants, a fertiliser factory and an oil refinery.

\section{Materials and methods}

\subsection{Sample preservation and analysis}

A laser fluorimeter manufactured by Quantalase Enterprises Pvt. Ltd., Indore, India, was used to measure the concentration of uranium up to $\mathrm{ppb}$ level $(\mu \mathrm{g} / \mathrm{l})$. The laser fluorimeter consists of a sealed nitrogen laser tube as an excitation source with a wavelength of $337.1 \mathrm{~nm}$, a sample compartment and a photomultiplier tube (PMT). The detector is placed at a right angle to the radiation source to avoid the background signal. The laser source emits an intense pulsed ultraviolet radiation of $337.1 \mathrm{~nm}$ carrying energy of $20 \mu \mathrm{J}$ of width $7 \mathrm{~ns}$ with a repetition time of 10 pulses per second (Sahoo et al., 2009). Fluorescence interference due to organic matter is removed by using a proper electronic delay, optical filter and gating technology (Veselsky et al., 1988). The fluorescence signals from the PMT are integrated for 4 seconds and then displayed. 
Samples were collected from the different sources of drinking water in acidclean and tightly closed polyethylene $500-\mathrm{ml}$ bottles for uranium analysis. In the study region, the majority of the population uses the groundwater for drinking purposes. Only a very small proportion of the population uses canal and ROtreated water for drinking purposes. In this study, 147 samples of groundwater, 6 samples of canal water and 6 samples of RO-treated water were collected and analysed. RO-treated water was collected from the government-installed ROs in 6 villages of the study region. Each sample was brought to $\mathrm{pH}$ range $6.5-7.5$ before analysis to overcome the quenching effect due to the presence of high acidic concentration (Veselsky et al., 1988). The presence of a high quantity of other interfering materials (such as iron, manganese, etc.) can cause the quenching effect. So, the standard addition method, explained below, is used for the uranium analyses by laser fluorimeter to avoid the matrix effect.

\subsection{Analytical procedure}

$5 \mathrm{ml}$ of a water sample was placed in the dry and clean quartz cell along with $0.5 \mathrm{ml}$ of $5 \%$ sodium pyrophosphate of $\mathrm{pH}$ value 7 . The instrument was calibrated with standard uranium solution of known concentration. Both micropipettes and an analytical balance were used for the measurements to avoid errors. The concentration of uranium in samples was calculated by:

$$
U(\mu \mathrm{g} / \mathrm{l})=\frac{D 1}{D 1-D 2} \frac{V 1}{V 2} C
$$

$D 1$ is fluorescence due to the sample only, $D 2$ is fluorescence due to the sample and spiked uranium standard, $V 1$ is the volume of $U$ standard added, $V 2$ is the volume of sample taken and $C$ is the concentration of the $U$ standard solution (Sahoo et al., 2009).

\subsection{Risk assessment}

In the present investigation, two types of risks associated with uranium were evaluated. One is the radiological risk due to uranium as a radioactive element, and the second is the chemical toxicity due to uranium as a heavy metal.

\subsubsection{Radiological risk assessment}

The radiological risk was calculated by the USEPA method (USEPA, 2000). The excess cancer risk associated with intake of uranium nuclide was estimated as follows:

activity concentration of uranium $(\mathrm{Bq} / \mathrm{l})=$

mass concentration of uranium $(\mu \mathrm{g} / \mathrm{l}) \times$ conversion factor $(0.025 \mathrm{~Bq} / \mu \mathrm{g})$, 


$$
\begin{gathered}
\text { risk factor }(\mathrm{per} \mathrm{Bq} / \mathrm{l})= \\
\text { cancer risk coefficient }\left(1.19 \times 10^{-9} \mathrm{~Bq}^{-1}\right) \times \text { water intake, } \\
\text { excess cancer risk }= \\
\text { activity concentration of uranium }(\mathrm{Bq} / \mathrm{l}) \times \text { risk factor }(\text { per } \mathrm{Bq} / \mathrm{l}) .
\end{gathered}
$$

The average Indian life expectancy for males and females in India is 63.7 years, i.e. 23250 days (HDR, 2009), and daily consumption of water was set as $4.051 /$ day (Jain et al., 1994). Thus, the total lifetime water intake turns out to be 94162.5 liters. The reported value of $1.19 \times 10^{-9} \mathrm{~Bq}^{-1}$ of the cancer risk coefficient of uranium was used as given by USEPA in equation (3) (EPA, 1999; UNSCEAR, 2000).

\subsubsection{Chemical toxicity risk}

The chemical toxicity risk in the drinking water samples due to the uranium concentration was estimated in terms of the $L A D D$ (lifetime average daily dose, $\mu \mathrm{g} \cdot \mathrm{kg}^{-1} . \mathrm{day}^{-1}$ ) using the following formula (Ye-shin et al., 2004):

$$
L A D D\left(\mu \mathrm{kg} \mathrm{kg}^{-1} \cdot \mathrm{day}^{-1}\right)=\frac{E P C \times I R \times E F \times E D}{A T \times B W}
$$

where $L A D D=$ lifetime average daily dose $\left(\mu \mathrm{g} \cdot \mathrm{kg}^{-1} \cdot \mathrm{day}^{-1}\right), E P C=$ exposure point concentration $(\mu \mathrm{g} / \mathrm{l}), I R=$ water ingestion rate $(\mathrm{l} / \mathrm{day}), E F=$ exposure frequency (days/year), $E D=$ total exposure duration (years), $A T=$ average time (days) and $B W=$ body weight.

The water ingestion rate was set as $4.05 \mathrm{l} /$ day due to the highly humid conditions (Jain et al., 1995). The exposure frequency is 350 days. 63.7 years is the total exposure duration, i.e. the average Indian life expectancy for both males and females (HDR, 2009). 23250 days is the average time calculated $(63.7 \times 365$ days) and $51.5 \pm 8.5 \mathrm{~kg}$ (Dang et al., 1996) was the average body weight taken of an Indian man. The hazard quotient $(H Q)$ is given by:

$$
H Q=\frac{L A D D}{R F D} .
$$

Here, $R F D$ is the reference dose calculated on the basis of the AERB permissible limits $(60 \mu \mathrm{g} / \mathrm{l})\left(\mathrm{AERB}, \mathrm{DAE}\right.$, India, 2004) and turned out to be $4.53 \mu \mathrm{g} . \mathrm{kg}^{-1}$.day ${ }^{-1}$.

Animal studies have identified the kidney as the most sensitive organ of uranium toxicity (Luessenhop et al., 1958). The Royal Society has also concluded that the acute exposures that lead to concentrations of uranium of $1 \mu \mathrm{g} / \mathrm{g}$ in the kidney have been associated with minor kidney dysfunction and the chronic level 
TABLE I

Safe limits for the uranium concentration in drinking water recommended by different health organisations.

\begin{tabular}{|c|c|c|c|c|}
\hline Health agency & $\begin{array}{c}\text { uranium } \\
\text { concentration }\end{array}$ & excess cancer risk & reference dose $^{2}$ & reference \\
\hline WHO & 30 & $8.4 \times 10^{-5}$ & 2.26 & WHO, 2011 \\
\hline Health Canada & 20 & $5.6 \times 10^{-5}$ & 1.51 & Ye-shin et al., 2004 \\
\hline USEPA & 30 & $8.4 \times 10^{-5}$ & 2.26 & USEPA, 2003 \\
\hline AERB & 60 & $1.68 \times 10^{-4}$ & 4.53 & AERB, DAE, India, 2004 \\
\hline
\end{tabular}

that leads to minor kidney dysfunction is not well established but likely to be $0.3 \mu \mathrm{g} / \mathrm{g}$ in the kidney (Royal Society, 2002). The nephrotoxic effects of uranium are due to its chemical properties. The threshold concentration of $3 \mu \mathrm{g} / \mathrm{g}$ in the kidney for uranium was proposed (Spoor and Hursh, 1973).

\section{Results and discussion}

Different health organisations have recommended different safe limits for the uranium concentration in drinking water, as shown in Table I. The excess cancer risk and reference dose are measured according to these safe limits. The average daily water intake, body weight and life expectancy were taken according to Indian standards, as discussed above in the risk assessment methodologies. However, in the present study, the results were compared with the AERB safe limits.

In the present investigations, 159 samples of drinking water of the Bathinda district were analysed to measure chemical and radiological toxicity. Various statistical parameters, i.e. the mean, median, maximum value, minimum value, 5 th percentile, 95th percentile, 25th percentile and 75th percentile of various quantities, i.e. the mass concentration of uranium, radiological risk, $L A D D$ and hazard quotient were evaluated and are reported in Table II. The mass concentration of uranium was found to vary in the range of 0.48 to $571.7 \mu \mathrm{g} / \mathrm{l}$, with a mean concentration of $84.70 \mu \mathrm{g} / \mathrm{l}$. Out of the analysis of 159 drinking water samples, only $28(17.6 \%)$ were found to be below $15 \mu \mathrm{g} / 1$; $43(26 \%)$ were found to be below $30 \mu \mathrm{g} / \mathrm{l}$, the permissible limit recommended by USEPA (2003) and WHO (2011); and $81(50.9 \%)$ samples were found to be below $60 \mu \mathrm{g} / \mathrm{l}$, the permissible limit recommended by the AERB (AERB, DAE, India, 2004). The pi chart for the number of samples in different ranges of uranium concentration is shown in Figure 2. The excess cancer risk associated with uranium concentration was found 
TABLE II

Various statistical parameters calculated from Bathinda district drinking water samples.

\begin{tabular}{ccccc}
\hline parameter & uranium concentration $^{1}$ & excess cancer risk & LADD & $H Q$ \\
\hline Mean & 84.70 & $2.37 \times 10^{-4}$ & 6.38 & 1.41 \\
Median & 57.00 & $1.60 \times 10^{-4}$ & 4.30 & 0.95 \\
Range & $0.48-571.7$ & $1.34 \times 10^{-6}-1.60 \times 10^{-3}$ & $0.04-43.11$ & $0.01-9.52$ \\
$\mathrm{Q}_{25}$ & 25.75 & $7.21 \times 10^{-5}$ & 1.94 & 0.43 \\
$\mathrm{Q}_{75}$ & 114.2 & $3.20 \times 10^{-4}$ & 8.61 & 1.90 \\
$\mathrm{P}_{5}$ & 3.64 & $1.02 \times 10^{-5}$ & 0.27 & 0.06 \\
$\mathrm{P}_{95}$ & 223.5 & $6.26 \times 10^{-4}$ & 16.86 & 3.72 \\
\hline
\end{tabular}

${ }^{1}$ Expressed as $\mu \mathrm{g} / \mathrm{l} ;{ }^{2}$ Expressed as $\mu \mathrm{g} \cdot \mathrm{kg}^{-1}$.day ${ }^{-1} ; \mathrm{Q}_{25}=1 \mathrm{st}$ quartile, $\mathrm{Q}_{75}=3$ rd quartile, $\mathrm{P}_{5}=5$ th percentile, $\mathrm{P}_{95}=95$ th percentile, $L A D D=$ lifetime average daily dose, $H Q=$ hazard quotient.

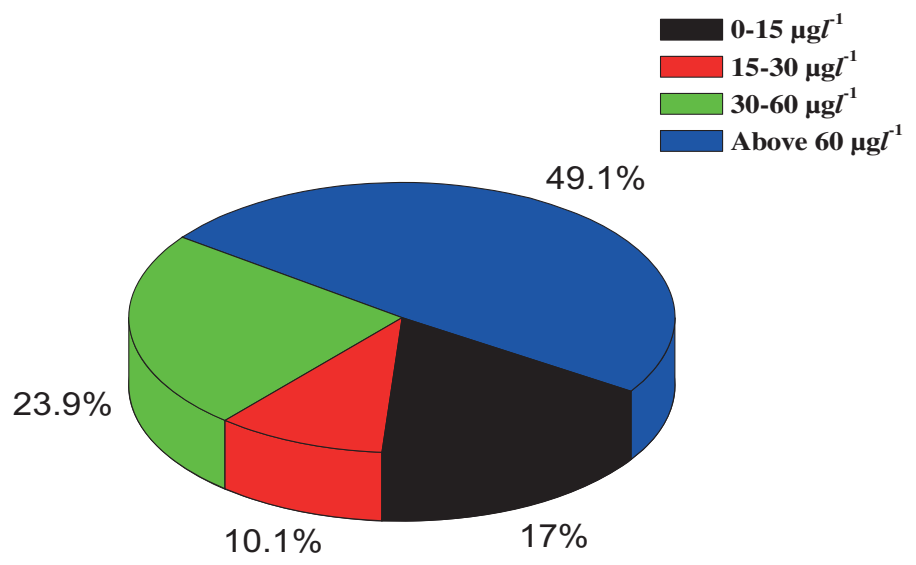

Figure 2 - Pi chart representation of the number of samples collected in the above ranges of uranium concentration.

to be in the range $1.34 \times 10^{-6}$ to $1.60 \times 10^{-3}$ with a mean value of $2.37 \times 10^{-4}$, which is greater than the AERB permissible limit of $1.68 \times 10^{-4}$ (AERB, DAE, India, 2004). The estimated lifetime average daily dose ( $L A D D)$ was observed to be between $0.04-43.11 \mu \mathrm{g} . \mathrm{kg}^{-1}$. day ${ }^{-1}$ with a mean value of $6.38 \mu \mathrm{g} \cdot \mathrm{kg}^{-1}$.day ${ }^{-1}$. It was observed that the concentration of uranium in reverse osmosis-(RO) treated and canal water samples was within permissible limits, whereas the groundwater showed quite a high concentration of uranium.

In the same study region, Kumar et al. have carried out similar investigations (Kumar et al., 2011). In their study, they investigated 235 water samples from four 
TABLE III

RO-treated water samples (number of samples $=6$ ).

\begin{tabular}{ccccc}
\hline parameter & uranium concentration $^{1}$ & excess cancer risk & $L A D D^{2}$ & $H Q$ \\
\hline mean & 3.21 & $8.98 \times 10^{-6}$ & 0.24 & 0.05 \\
median & 2.66 & $7.44 \times 10^{-6}$ & 0.20 & 0.04 \\
range & $0.48-8.30$ & $1.34 \times 10^{-6}-5.78 \times 10^{-6}$ & $0.04-0.63$ & $0.01-0.14$ \\
$\mathrm{Q}_{25}$ & 2.06 & $5.78 \times 10^{-6}$ & 0.16 & 0.03 \\
$\mathrm{Q}_{75}$ & 3.13 & $8.76 \times 10^{-6}$ & 0.24 & 0.05 \\
$\mathrm{P}_{5}$ & 0.86 & $2.41 \times 10^{-6}$ & 0.06 & 0.01 \\
$\mathrm{P}_{95}$ & 7.03 & $1.97 \times 10^{-5}$ & 0.53 & 0.12 \\
\hline
\end{tabular}

${ }^{1}$ Expressed as $\mu \mathrm{g} / \mathrm{l} ;{ }^{2}$ expressed as $\mu \mathrm{g} \cdot \mathrm{kg}^{-1}$. $\mathrm{day}^{-1} ; \mathrm{Q}_{25}=1$ st quartile, $\mathrm{Q}_{75}=3$ rd quartile, $\mathrm{P}_{5}=5$ th percentile, $\mathrm{P}_{95}=95$ th percentile, $L A D D=$ lifetime average daily dose, $H Q=$ hazard quotient.

districts (Bathinda, Mansa, Ferozepur and Faridkot) of Punjab. Of these 235 samples, 80 samples were from the present study region. The uranium concentration in these 80 water samples ranged from 2-644 ppb with a mean of $80.83 \mathrm{ppb}$. In the present work, in the 159 water samples analysed, the average of $84.70 \mathrm{ppb}$ of uranium concentration did not differ significantly. It confirms that the uranium content in the subsurface water of the study region is above the permissible limits.

In RO-treated water samples, the concentration of uranium was found to vary from $0.48-8.30 \mu \mathrm{g} / \mathrm{l}$ with a mean value of $3.21 \mu \mathrm{g} / \mathrm{l}$, and is reported in Table III. All samples have a concentration of uranium within the permissible limits recommended by the AERB. A comparison of RO-treated water samples with groundwater samples shows that the RO system was effective in lowering the uranium concentration of the water by up to $90 \%$. This was also supported by an earlier published report (WHO, 2011). In canal water samples, the concentration of uranium was found to vary from $3.00-8.20 \mu \mathrm{g} / \mathrm{l}$ with a mean value of $5.18 \mu \mathrm{g} / \mathrm{l}$, and is reported in Table IV. It was further observed that the concentration of uranium in canal water was also within the permissible limits. The maximum value of the radiological risk was found to be $5.78 \times 10^{-6}$ and $2.30 \times 10^{-5}$ in the case of RO-treated water samples and canal water samples, respectively, which is less than the AERB permissible limit $\left(1.68 \times 10^{-4}\right)$ (AERB, DAE, India, 2004). The RO-treated and canal water samples were found to be safe for drinking from a radiological and chemical toxicity risk point of view.

The statistical parameters for mass concentration of uranium, radiological risk and chemical toxicity of groundwater samples are presented in Table V. It was observed that the mean concentration of uranium and mean radiological risk were $91.91 \mu \mathrm{g} / \mathrm{l}$ and $2.57 \times 10^{-4}$, respectively, which is higher $(53.2 \%)$ than the AERB 
TABLE IV

Canal water samples (number of samples $=6$ ).

\begin{tabular}{|c|c|c|c|c|}
\hline parameter & $\begin{array}{c}\text { uranium } \\
\text { concentration }\end{array}$ & excess cancer risk & $L A D D^{2}$ & $H Q$ \\
\hline mean & 5.18 & $1.45 \times 10^{-5}$ & 0.39 & 0.09 \\
\hline median & 5.08 & $1.42 \times 10^{-5}$ & 0.38 & 0.08 \\
\hline range & $3.00-8.20$ & $8.40 \times 10^{-6}-2.30 \times 10^{-5}$ & $0.23-0.62$ & $0.05-0.14$ \\
\hline $\mathrm{Q}_{25}$ & 3.89 & $1.09 \times 10^{-5}$ & 0.29 & 0.06 \\
\hline $\mathrm{Q}_{75}$ & 5.96 & $1.67 \times 10^{-5}$ & 0.45 & 0.10 \\
\hline $\mathrm{P}_{5}$ & 3.15 & $8.82 \times 10^{-6}$ & 0.24 & 0.05 \\
\hline $\mathrm{P}_{95}$ & 7.69 & $2.15 \times 10^{-5}$ & 0.58 & 0.13 \\
\hline
\end{tabular}

${ }^{1}$ Expressed as $\mu \mathrm{g} . \mathrm{l}^{-1} ;{ }^{2}$ expressed as $\mu \mathrm{g} . \mathrm{kg}^{-1}$. day $^{-1} ; \mathrm{Q}_{25}=1$ st quartile, $\mathrm{Q}_{75}=3$ rd quartile, $\mathrm{P}_{5}=5$ th percentile, $\mathrm{P}_{95}=95$ th percentile, $L A D D=$ lifetime average daily dose, $H Q=$ hazard quotient.

TABLE V

Groundwater samples (number of samples $=147$ ).

\begin{tabular}{ccccc}
\hline Parameter & Uranium Concentration $^{1}$ & Excess Cancer Risk & LADD $^{2}$ & HQ \\
\hline mean & 91.91 & $2.57 \times 10^{-4}$ & 6.93 & 1.53 \\
median & 65.20 & $1.83 \times 10^{-4}$ & 4.91 & 1.09 \\
range & $3.10-571.7$ & $8.68 \times 10^{-6}-1.60 \times 10^{-3}$ & $0.23-43.11$ & $0.05-9.52$ \\
$\mathrm{Q}_{25}$ & 39.4 & $1.10 \times 10^{-4}$ & 2.97 & 0.65 \\
$\mathrm{Q}_{75}$ & 124.5 & $3.49 \times 10^{-4}$ & 9.38 & 2.07 \\
$\mathrm{P}_{5}$ & 10.77 & $3.02 \times 10^{-5}$ & 0.81 & 0.18 \\
$\mathrm{P}_{95}$ & 229.5 & $6.43 \times 10^{-4}$ & 17.31 & 3.82 \\
\hline
\end{tabular}

${ }^{1}$ Expressed as $\mu \mathrm{g} / \mathrm{l} ;{ }^{2}$ expressed as $\mu \mathrm{g} . \mathrm{kg}^{-1}$.day ${ }^{-1} ; \mathrm{Q}_{25}=1$ st quartile, $\mathrm{Q}_{75}=3 \mathrm{rd}$ quartile, $\mathrm{P}_{5}=5$ th percentile, $\mathrm{P}_{95}=95$ th percentile, $L A D D=$ lifetime average daily dose, $H Q=$ hazard quotient.

permissible limit of $1.68 \times 10^{-4}$ (AERB, DAE, India, 2004). It means that $2-3$ persons out of 10000 may be prone to cancer. The 95th percentile was considered to be the worst case and the worst case of radiological risk was calculated as $6.43 \times 10^{-4}$, which means that 6-7 persons out of 10000 may be cancer patients. The mean value of the hazard quotient was calculated as 1.53 and the hazard quotient value for the worst case was 3.82.

Groundwater showed higher levels of uranium than canal and RO-treated water samples. The box whisker plot of uranium concentration in water samples at different depth ranges, canal water samples and RO-treated water samples is shown in Figure 3. The depth interval of 200-300 feet was found to have the highest mean concentration of $121 \mu \mathrm{g} / \mathrm{l}$ in the groundwater samples. No correlation of uranium concentration was found with depth. Therefore, a possible reason for 


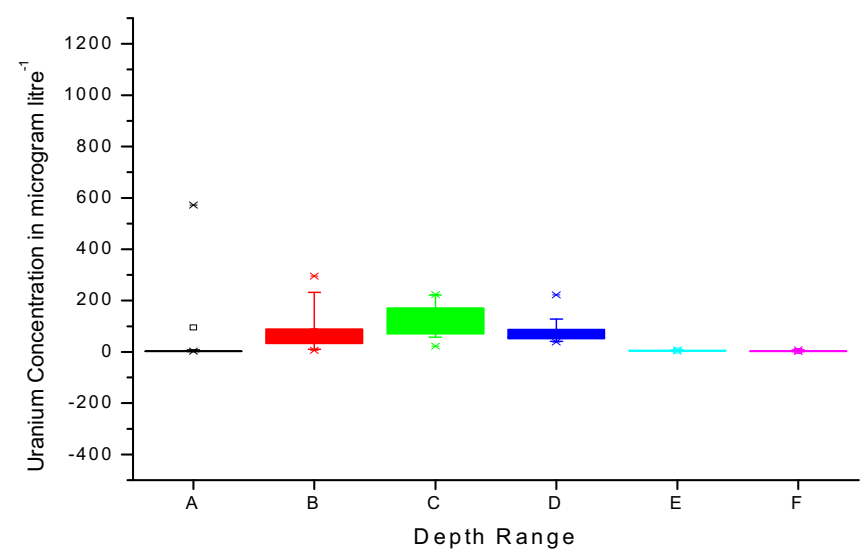

Figure 3 - Box whisker plot of uranium concentration in groundwater with different depth ranges, canal water and RO-treated water samples. $A$ in the graph stands for the groundwater sample depth in the range 0-100 feet, B for 100-200 feet, C for 200-300 feet, D above 300 feet. E and $F$ represent canal water and $R O-$-treated samples, respectively.

the high concentration of uranium in groundwater samples may be due to leaching of uranium through the soil to groundwater by the heavy use of phosphate fertilisers in the studied area. It has been established that the use of phosphate fertilisers may enrich the soil with uranium (Schnug and Haneklaus, 2008). The soil of the study region is rich in $\mathrm{CaCO}_{3}$ (Gill et al., 2005) and the leaching of uranium in the carbonate medium has already been confirmed by some authors (Mason et al., 1997).

\section{Conclusion}

The present results reveal that negligible radiological risk and chemical toxicity were found among the drinking water samples of the study region at the 5th percentile, but the water samples of the study region were found to have a high value of the excess cancer risk, $6.26 \times 10^{-4}$, which means about 6-7 persons out of 10000 people may be prone to cancer, and a high value of the hazard quotient; 3.72. This means that the uranium contamination in the drinking water samples was found to be 3.72 times the AERB safe limit. The mean hazard quotient was found to be 1.41 , which is also greater than 1 . The drinking water samples collected had mean radiological risk and chemical toxicity greater than the permissible limits of the AERB. It was concluded that the RO-treated water samples and canal water samples have a uranium concentration within the permissible limits recommended by different organisations and are considered to be safe for drinking, but the groundwater samples of the study region have a 
uranium concentration higher than the safe limits recommended by the different organisations in Table I and are considered to be unfit for drinking without any treatment.

Acknowledgments. The research team is grateful to BARC, Trombay, India, for providing financial assistance for carrying out the present study.

\section{REFERENCES}

AERB, DAE, India (2004) Atomic Energy regulatory Board, Department of atomic energy, India, Drinking water specification.

Dang H.S. et al. (1996) Age dependent physical and anatomical Indian data for application in internal dosimetry, Radiat. Prot. Dosim. 63, 217-222.

Domingo J.L. et al. (1989) The development toxicity of uranium in mice, Toxicology 55, 143-152.

EPA (1999) Environmental Protection Agency, Cancer risk coefficients for Environmental exposure to radionuclides, Federal Guidance Report No. 13 (EPA.402 R-99-001).

Gill G.S. et al. 2005 Geochemical studies on groundwater from parts of Bathinda district (Punjab) and Sirsa district (Haryana), J. Appl. Geochem. 7 (2), 248-255.

Health Canada (1999) Uranium in drinking water, Document for public comment prepared by federal provincial subcommittee on drinking water.

HDR (2009) Human Development Report, National Resource Centre for urban poverty and all India institute of Local Self Government, Mumbai.

Jain S.C. et al. (1995) Formulation of reference Indian adult anatomic and physiological data, Health Phys. 68 (4), 509-522.

Kurttio P. et al. (2002) Renal effects of uranium in drinking water, Environ. Health Perspect. 110 (4), 337-342.

Kurttio P. et al. (2006) Kidney toxicity of ingested uranium from drinking water, Am. J. Kidney Dis. 47 (6), 972-982.

Kumar A. et al. (2011) Risk assessment for natural uranium in subsurface water of Punjab State, India, Human Ecol. Risk Assess. 17, 381-393.

Larivière D. et al. (2007) Age dependence of natural uranium and thorium concentrations in bone, Health Phys. 92, 119-126.

Luessenhop A.J. et al. (1958) The toxicity in the man of hexavalent uranium following intravaneous administration, Am. J. Roentgenol. 79 (1), 83-100.

Mason C.F.V. et al. (1997) Carbonate leaching of Uranium from contaminated soils, Environ. Sci. Technol. 31, 2707-2711.

Royal Society (2002) The health hazards of depleted uranium munitions, Part II Policy Document 5/02 The Royal Society, London.

Sahoo S.K. et al. (2009) Distribution of uranium in drinking water and associated age-dependent radiation dose in India, Radiat. Prot. Dosim. 136, 108-113.

Schnug E., Haneklaus S. (2008) Dispersion of uranium in environment by fertilization, edited by B.J. Merkel, A. Hasche-Berger. Uranium, Mining and Hydrogeology. Springer, Berlin, Heidelberg ISBN: 978-3-540-87745-5.

Singh J. et al. (1994) High U-contents observed in some Drinking waters of Punjab, India, J. Environ. Radioact. 26, 217-222. 
Spoor N.L., Hursh J.B. (1973) Protection criteria in uranium, plutonium, transplutonic elements, Handbook of experimental Pharmalogy, volume 36, edited by H.L. Hodge, J.N. Stannard, J.B. Hursh. Sringer-Verlag, New York, pp. 241-270.

USEPA (2000) United States Environmental Protection Agency, National Primary Drinking Water Regulations; Radionuclides, Final Rule. 40 CFR parts 9,141 and 142, pp. 76708-76712.

USEPA (2003) United States Environmental Protection Agency, Current Drinking Water Standards, Ground water and drinking water protection agency, pp 1-12.

UNSCEAR (2000) United Nations Scientific Committee on effects of Atomic Radiation, Sources, effects and risks of ionizing radiation, Report to general Assembly, ISBN 92-1-142238-8, New York.

Veselsky J.C. et al. (1988) Determination of uranium in minerals by laser HYPERLINK, Analyst. 113, 451-455.

WHO (1998) World Health Organization, Guidelines for Drinking water quality, Addendum to volume 2,WHO, Geneva.

WHO (2008) World Health Organization, Meeting the MDG drinking water and sanitation target: the urban and rural challenge of decade.

WHO (2011) World Health Organization, Uranium in Drinking water, Background document for development of WHO guidelines for drinking water quality.

Ye-shin K. et al. (2004) Health risk assessment for uranium in Korean groundwater, $J$ Environ. Radioact. 77, 77-85.

Zamora M.L. et al. (1998) Chronic Ingestion of Uranium in Drinking Water: A Study of Kidney Bioeffects in Humans, Toxicol Sci. 43, 31-45. 